\title{
Game Theoretic Modeling of NGANs: Impact of retail and wholesale services price variation
}

\author{
João Paulo R. Pereira \\ Polytechnic Institute of Bragança (IPB), Portugal \\ jprp@ipb.pt \\ Pedro Ferreira \\ Technical University of Lisbon (IST), Portugal \\ pedrof@cmu.edu
}

\begin{abstract}
The increasing demand for broadband access leads operators to upgrade the existing access infrastructures (or building new access network). Broadband access networks require higher investments (especially passive infrastructures such as trenches/ducts and base station towers/masts), and before making any decision it is important to analyze all solutions. The selection of the best solution requires understanding the technical possibilities and limitations of the different access technologies, as well as understanding the costs of building and operating the networks. This study analyzes the effect of asymmetric retail and wholesale prices on operators' NPV, profit, consumer surplus, welfare, retail market, wholesale market, and so on. For that, we propose a tehno-economic model complemented by a theoretic-game model. This tool identifies all the essential costs of building (and operating) access networks, and performs a detailed analysis and comparison of the different solutions in various scenarios. Communities, operators/service providers, and regulators can use this tool to compare different technological solutions, forecast deployment costs, compare different scenarios, and so on, and help them in making deployment (or regulatory) decisions. The game-theory analyses give a better understanding of the competition and its effect on the business case scenarios' economic results.
\end{abstract}

Index Terms - Next generation networks (NGN), Cost model, Game-theory model, Segmented regulation

\section{INTRODUCTION}

Service providers, network operators, and Internet access providers are faced with the challenge of providing higher capacity access to the end user and offering wider services [1]. Consequently, new Internet infrastructure and technologies that are capable of providing high-speed and high-quality services are needed to accommodate multimedia applications with diverse quality of service (QoS) requirements. Until a few years ago, Internet access for residential users was almost exclusively provided via public switched telephone networks (PSTN) over the twisted copper pair [2]. The new quadruple play services (i.e., voice, video, data, and mobility), which require high-speed broadband access,

Manuscript received October 25, 2011; revised November 3, 2011; accepted November 25, 2011. created new challenges for the modern broadband wireless/wired access networks [3]. The new services led to both the development of several different last-mile solutions to make the access network capable of supporting the requirements and a stronger integration of optical and wireless access networks.

The move toward next-generation networks (NGNs) has significant implications for the technical architecture and design of access network infrastructure, as well as the value chains and business models of electronic communications service provision [4]. This migration has begun to transform the telecommunication sector from distinct single-service markets into converging markets [5]. NGNs allow consumers to choose between different access network technologies to access their service environment. In our work, the NGN architecture will be limited to the developments of network architectures in the access network (local loop), referred to as the nextgeneration access network (NGAN).

Although the cost of bandwidth in the active layer has reduced significantly (and continually) in recent years, the cost of civil works (such as digging and trenching) represents a major barrier for operators to deploy NGA infrastructure. Studies and deployments [6] show that civil infrastructure is the largest proportion of the costs of fixed access deployment (up to $80 \%$ ). Duct is a critical part of the next-generation access networks and its sharing would reduce or eliminate this capital cost and barrier to entry. However, duct access may need to be complemented by extra civil work to increase infrastructure capacity, the use of dark fiber (where available), or the use of conduits of alternative infrastructure providers. This also highlights that different and/or complementary regulatory tools may be required in different parts of the network [7].

\section{EFFECTS OF NGNS ON MARKET DEFINITION}

The entry of new competitors can be based on the resale of services from the incumbent, on building up their own infrastructures, on renting unbundled infrastructure from incumbents, or, on the combination of the above elements. The availability of these options to competitors and price definition are generally determined by regulatory policies [8]. So, the introduction of NGNs 
by telecommunication network operators obligates the national regulators adapt their access regulation regimes to the new technological conditions. Regulation and/or promotion of competition by regulatory measures need to be analyzed and compared.

The access network is usually the most expensive component in terms of capital investment (specifically passive infrastructure) and OA\&M costs. Of the several costs, civil engineering costs are greatest when it is necessary to run a new fiber or copper connection to the cabinet, building, or home. Moreover, access to existing infrastructure, such as the ducts of the incumbent or other market players or sewage pipes, is critically important to avoid digging.

For [9], a local loop network can be divided into three main layers or segments: a service layer and two infrastructure layers (see Figure 1). Layer 1 includes passive infrastructures, such ducts and cables, and requires the greatest investment. Layer 2 consists of active infrastructures, such as the technical installations at the end of the fibers that send, receive, and manage the optical signals. Layer 3 includes several services that consumers buy from telecommunication operators.

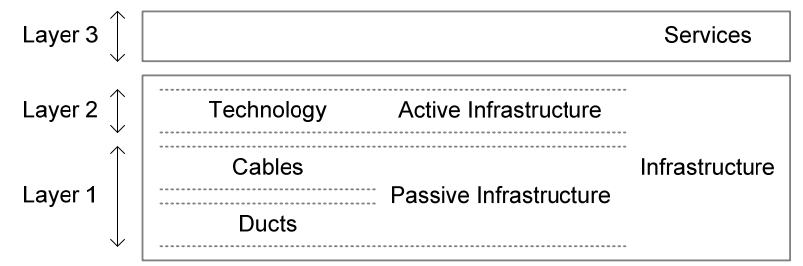

Figure 1. Network layers [9]

\section{BUSINESS CASE DEFINITION}

The definition of a business case implies a great number of assumptions, such as the penetration rate, components prices, and the market share rate. However, it is difficult to get an exact forecast of its performance. The utility of a business case is to offer a more approximated estimation that allows the construction of scenarios for the future. A business case should be as realistic as possible in order to be useful and reflect all the variables of interest of the market, as well as their evolution and expected behavior [10].

\section{A. Territory and demography}

The geographical areas considered are an area with high population density and an area with low population density and high coverage. For the rural area, the rollout strategy does not cover the whole area $(1173 \mathrm{~km} 2)$ - the target area is limited to $34.04 \mathrm{~km} 2$ with 23,000 inhabitants (see next table). In our model, we consider the last 10 years to estimate the average rate of increase: $0.62 \%$ for the urban area and value of $0.01 \%$ for rural target area. The population density in the urban area is 3,748 inhabitants per square kilometer and 675 in the rural.

Parameters presented in next table are important to calculate the cost of trenches/ducts, which are the most significant proportion of the costs of fixed access deployment.

TABLE I. AVERAGE LENGTHS ASSUMPTIONS

\begin{tabular}{|c|c|c|}
\hline Segment & Region 1 - Urban & Region 2 - Rural \\
\hline Feeder & $750 \mathrm{~m}$ & $1500 \mathrm{~m}$ \\
\hline Distribution & $300 \mathrm{~m}$ & $750 \mathrm{~m}$ \\
\hline Drop & $15 \mathrm{~m}$ & $25 \mathrm{~m}$ \\
\hline
\end{tabular}

Several studies and models [11-13] assume that in urban areas, the duct availability rate is about $60 \%$ for feeder segments, and $40 \%$ for the distribution segment. In rural areas, the duct availability rate is $25 \%$ for feeder and $0 \%$ for the distribution network. The report from [14] assumes that a substantial proportion (80\% near to the $\mathrm{CO}$ and $30 \%$ nearer to the premises) of existing ducts can be re-used for fiber deployment [15].

\section{B. Service profiles assumptions}

In this business case, we define two different services: slow Internet browsing service with downstream throughput of $2 \mathrm{Mbps}$, and triple play service with 20 Mbps of downstream rate. The expected tariff evolution (the factor by which the tariff is expected to increase or decrease annually) is defined for both tariffs: connection and monthly fee (see next table).

The assumptions presented are based in the data from the review of the literature. We observe that several studies and deployments [11, 16-20] use the yearly price erosion of between $5 \%$ and $15 \%$. The service price assumptions (prices and annual variation) are presented in next table.

TABLE II. SERVICE PROFILE CHARACTERISTICS: RETAIL PRICES

\begin{tabular}{|c|c|c|c|c|}
\hline $\begin{array}{c}\text { Service } \\
\text { Profiles }\end{array}$ & $\begin{array}{c}\text { One time } \\
\text { Activation } \\
\text { Fees } \\
\text { (Connection) }\end{array}$ & $\begin{array}{c}\text { Expected } \\
\text { tariff } \\
\text { evolution [\%] }\end{array}$ & $\begin{array}{c}\text { Monthly } \\
\text { Subscription } \\
\text { Fees }\end{array}$ & $\begin{array}{c}\text { Expected } \\
\text { tariff } \\
\text { evolution [\%] }\end{array}$ \\
\hline Serv. 1 & $100 €$ & $-10 \%$ & $20 € /$ month & $-5 \%$ \\
\hline Serv. 2 & $100 €$ & $-10 \%$ & $50 € /$ month & $-8 \%$ \\
\hline
\end{tabular}

\section{Broadband market forecasts}

Next figure shows the penetration forecast for DSL, HFC, fiber and WiMAX for urban areas. In 2020, for the urban area, the expected penetration rates for the fixed technologies are $1.5 \%$ for WiMAX, $14.25 \%$ for HFC, $22.71 \%$ for fiber, and $30.97 \%$ for DSL. In the rural area, the expected penetration rate in 2020 is $10.95 \%$ for HFC, 23.7\% for DSL, $16.41 \%$ for fiber, and $7.5 \%$ for FWA. We also assume that in rural areas the FWA operator has higher market share than in urban areas.

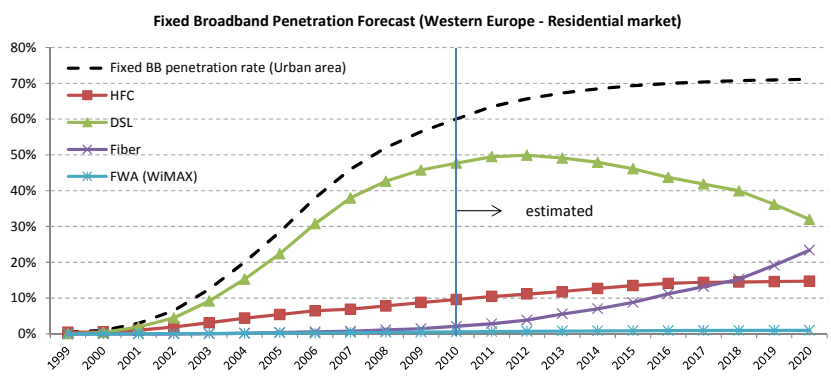

Figure 2. Fixed broadband penetration forecasts (2010-2020) 


\section{Competitive situation and operators market share}

In this section, the market share (relative size) of all the firms (operators) is projected. As competition between operators is different in each area, we estimate the market share for each operator depending on the area, technology, service, and the market.

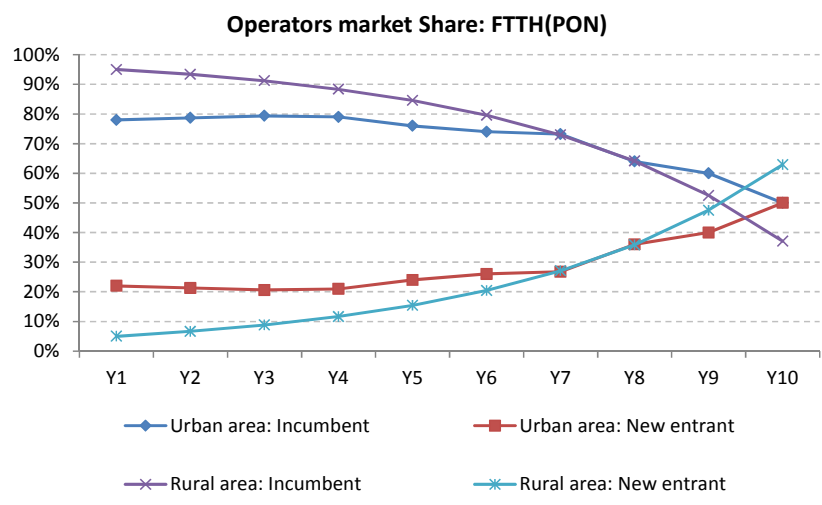

Figure 3. Market share per operator and region (FTTH market)

\section{GAME THEORY FOR COMPETING MODELING}

With game theory, we want to understand the effects of the interaction between the different players defined in our business case. In the proposed games, the profit (outcome) of each operator (player) will be dependent not only on their actions, but also on the actions of the other operators in the market.

This section analyzes the impact of the price (retail and wholesale) variations on several output results: players' profit, consumer surplus, welfare, costs, service adoption, and so on. For that, two price-setting games are played (Figure 4. ). Players' profits and NPV are used as the payoff for the players in the games analyzed.

From the several markets presented previously, in this section we present the results for FTTH (PON) market. We assume that two competing FTTH(PON) networks (incumbent operator and new entrant) are deployed in both areas. For the game-theoretic model, it is necessary to change the adoption model used in the technoeconomic model in a way that reflects the competition between players (see next Figure 5. ). We assume that the variation of the services prices of one player has an influence on the market share of all players (detailed in the next section).

In our model we also use the Nash equilibrium to find equilibrium. Proposed tools include a module to search the Nash equilibrium in the game. One strategy is a Nash equilibrium when both competitors play their best strategy related to the other strategies selected (players know each other's strategy in advance).

\section{A. Strategies}

To analyze the impact of retail and wholesale services price variations, we propose two games (see next figure): (1) analysis the impact of retail price variation on NPV (wholesale prices are defined by regulator); and (2) analysis the impact of retail and wholesale price variations on profit, consumer surplus, welfare, and retail/wholesale market (different wholesale prices in each region). For the game-theoretic evaluation, the model calculates the NPV and operator's profit for both operators' pricing strategies. Operators' NPVs are used as payoffs for the players in the first and second game, and operators' profits for the third game.

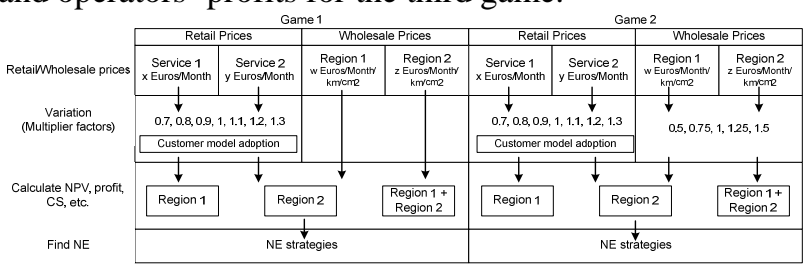

Figure 4. Games proposed

From the several assumptions, we posit: (a) the price that players charge for their services (retail and wholesale) will be varied; (b) the retail price setting will influence the market share of both players (resulting in a higher or lower market share); and (c) consumers only buy a retail service if the price is less than their willingness to pay.

As stated above, we assume that when one player increases/decreases the retail price, the market share of all players will be affected. For example, if one player offers cheaper services, it will be able to capture a higher market share. If a price decreases to nearly zero, everyone will use the service, and the market share of this operator will be close to $100 \%$ (total market). On the other hand, if an operator charges a higher price for a service, no one will subscribe to the service from this player, and its market share will decrease to $0 \%$.

\section{B. Adoption model}

The impact of varying retail prices on market shares is estimated using the Boltzmann equation.

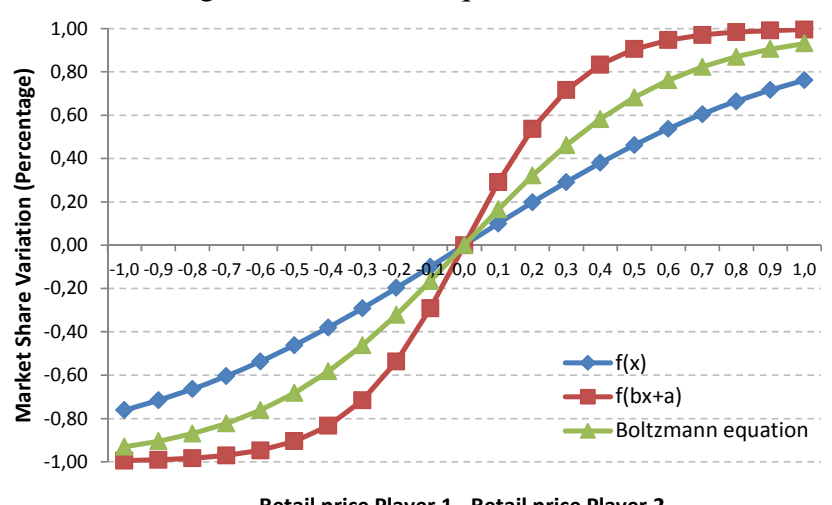

Figure 5. Models to estimate the impact of the price on the service adoption $(\mathrm{a}=0.4, \mathrm{~b}=3, \mathrm{dx}=0.3)$

\section{Main assumptions}

We assume that the willingness to pay for each retail service is different in both regions. In the urban area (region 1) the maximum amount subscribers would be willing to pay for service 1 is 26 euros and 65 euros for service 2 . In the rural area we assume a willingness value of 22 euros for service 1 and 55 euros for service 2 (see TABLE III. ). 
TABLE III. WILLINGNESS ASSUMPTIONS

\begin{tabular}{|l|c|c|c|c|}
\hline \multirow{2}{*}{ Parameters } & \multicolumn{2}{c|}{$\begin{array}{c}\text { Region 1 } \\
\text { (Urban area) }\end{array}$} & \multicolumn{2}{c|}{$\begin{array}{c}\text { Region 2 } \\
\text { (Rural area) }\end{array}$} \\
\cline { 2 - 5 } & Serv. 1 & Serv. 2 & Serv. 1 & Serv. 2 \\
\hline $\begin{array}{l}\text { Monthly Subscription } \\
\text { Fee (Year1) }\end{array}$ & $20 €$ & $50 €$ & $20 €$ & $50 €$ \\
\hline Willingness Value & $26 €$ & $65 €$ & $22 €$ & $55 €$ \\
\hline Willingness Multiplier & 1.3 & 1.3 & 1.1 & 1.1 \\
\hline
\end{tabular}

For the wholesale infrastructure we assume a duct availability of player $1100 \%$ in the urban area and $90 \%$ in the rural area. We also assume that operator 2 (new entrant) leases $100 \%$ of the ducts available in the urban area and $100 \%$ of the ducts available (operator 1 has only $90 \%$ and the remaining $10 \%$ are deployed by operator 2 ) in the rural area from operator 1 (incumbent operator). In the other hand, player 1 leases the 10\% remaining (in region 2) from operator 2. The wholesale prices assumptions are: $9.1 €$ (month / $\mathrm{km} / \mathrm{cm} 2$ ) for urban area and $7.5 €$ (month $/ \mathrm{km} \mathrm{/} \mathrm{cm2)} \mathrm{for} \mathrm{the} \mathrm{rural} \mathrm{area.} \mathrm{The}$ wholesale infrastructure assumptions and described in next table.

TABLE IV. WHOLESALE INFRASTRUCTURE ASSUMPTIONS

\begin{tabular}{|l|c|c|c|c|}
\hline \multirow{2}{*}{ Parameters } & \multicolumn{2}{|c|}{ Region 1 (Urban) } & \multicolumn{2}{c|}{ Region 2 (Rural) } \\
\cline { 2 - 5 } & $\begin{array}{c}\text { Feeder } \\
\text { segment }\end{array}$ & $\begin{array}{c}\text { Distribution } \\
\text { Segment }\end{array}$ & $\begin{array}{c}\text { Feeder } \\
\text { segment }\end{array}$ & $\begin{array}{c}\text { Distribution } \\
\text { Segment }\end{array}$ \\
\hline Provider 1 & \multicolumn{5}{|c|}{} \\
\hline Duct Availability & $100 \%$ & $100 \%$ & $90 \%$ & $90 \%$ \\
\hline $\begin{array}{l}\text { Wholesale price } \\
\text { charged to access } \\
\text { ducts (€/Km) }\end{array}$ & $€ 110$ & $€ 110$ & $€ 90$ & $€ 90$ \\
\hline $\begin{array}{l}\text { Proportion of } \\
\text { ducts leased }\end{array}$ & $0 \%$ & $0 \%$ & $10 \%$ & $10 \%$ \\
\hline From operator & - & - & 2 & 2 \\
\hline Provider 2 & $0 \%$ & $0 \%$ & $10 \%$ & $10 \%$ \\
\hline Duct Availability & $€ 110$ & $€ 110$ & $€ 90$ & $€ 90$ \\
\hline $\begin{array}{l}\text { Wholesale price } \\
\text { charged to access } \\
\text { ducts (€/Km) }\end{array}$ & $75 \%$ & $75 \%$ & $100 \%$ & $100 \%$ \\
\hline $\begin{array}{l}\text { Proportion of } \\
\text { ducts leased }\end{array}$ & 1 & 1 & 1 & 1 \\
\hline From operator & & & & \\
\hline
\end{tabular}

The next sections present the three games results and analyses. In the first game, retail prices vary between tariff multiplier 0.7 and 1.3 (in increments of 0.1 ). For the second game, retail prices vary between 0.8 and 1.2, and wholesale prices between 0.5 and 1.5 .

\section{Game 1: Impact of retail prices variation on NPV}

In this game we assume that wholesale prices are fixed and that operators choose retail prices to maximize their profit. The impact of varying retail prices on market shares is estimated using the Boltzmann equation (described above). The main goal of this analysis is to determine the optimal retail price strategy for both players. The retail prices vary between $-30 \%$ and $30 \%$, with increasing steps of $10 \%$ (next table).

TABLE V. RETAIL PRICES VARIATION VALUES

\begin{tabular}{|l|l|l|l|l|l|l|l|}
\hline $\begin{array}{l}\text { Tariff multiplier } \\
\text { factor }\end{array}$ & 0.7 & 0.8 & 0.9 & 1 & 1.1 & 1.2 & 1.3 \\
\hline Service 1 price & 14 & 16 & 18 & 20 & 22 & 24 & 26 \\
\hline Service 2 price & 35 & 40 & 45 & 50 & 55 & 60 & 65 \\
\hline
\end{tabular}

The combination of the two retail prices and seven multiplier factors leads to 49 possible strategies for each player $(49 \times 49$ matrix) in each region $(2,401$ total strategies). The next table presents the structure of the combinations and calculated NPV.

TABLE VI. STRUCTURE OF COMBINATIONS AND RESULTS FOR GAME 1

\begin{tabular}{|c|c|c|c|c|c|c|c|c|c|c|}
\hline \multirow{4}{*}{ 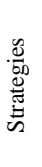 } & \multirow{3}{*}{\multicolumn{2}{|c|}{$\begin{array}{c}\text { Player 1 } \\
\begin{array}{c}\text { Retail } \\
\text { Price }\end{array} \\
\text { R1\& R2 }\end{array}$}} & \multirow{3}{*}{\multicolumn{2}{|c|}{$\begin{array}{c}\text { Player } 2 \\
\text { Retail } \\
\text { Price } \\
\text { R1 \&R 2 }\end{array}$}} & \multicolumn{6}{|c|}{ NPV } \\
\hline & & & & & \multicolumn{2}{|c|}{ Player 1} & \multicolumn{2}{|c|}{ Player 2} & $\begin{array}{l}\text { Tot. } \\
\text { P1 }\end{array}$ & $\begin{array}{l}\text { Tot. } \\
\text { P2 }\end{array}$ \\
\hline & & & & & \multirow{2}{*}{$\mathrm{R} 1$} & \multirow{2}{*}{$\mathrm{R} 2$} & \multirow{2}{*}{ R1 } & \multirow[b]{2}{*}{ R2 } & R1 & R1 \\
\hline & S1 & S2 & S1 & S2 & & & & & $\begin{array}{c}+ \\
\text { R2 }\end{array}$ & $\begin{array}{c}+ \\
\mathrm{R} 2\end{array}$ \\
\hline 1 & 0.7 & 0.7 & 0.7 & 0.7 & $\ldots$ & $\ldots$ & $\ldots$ & $\ldots$ & .. & $\ldots$ \\
\hline 2 & 0.7 & 0.7 & 0.7 & 0.8 & $\ldots$ & $\ldots$ & $\ldots$ & $\ldots$ & $\ldots$ & $\ldots$ \\
\hline $\mathrm{n}$ & $\ldots$ & $\ldots$ & $\ldots$ & $\ldots$ & $\ldots$ & $\ldots$ & $\ldots$ & $\ldots$ & $\ldots$ & $\ldots$ \\
\hline
\end{tabular}

The results (payoff matrix) of this game are presented in Table 11- shows the sum of the payoffs of each player in both regions. This table presents the NPV for both players for each possible combination of strategies (one strategy for each player); Nash equilibrium strategies are also identified.

The first two rows represents the prices multiplier factor of player 2 (for services 1 and 2) and the first two columns show the variation (multiplier factors) of player 1. Each cell contains two values: The left value corresponds to the NPV of player 1 , and the value on right side corresponds to the NPV of player 2. For example, the first value calculated (15831024€) corresponds to the NPV of player 1 when the strategy of player 1 is to decrease the price of service 1 and service 2 by about 30\% (multiplier factor 0.7 ), and the strategy of player 2 is also to decrease the price of service 1 and service 2 by about $30 \%$.

From these results presented in Table 11 we find three pure NE strategies (black cells) that are described in the next table. The next table shows the NE strategies that maximize the profit of both players. To maximize profit, in the first equilibrium strategy, operator 1 increases retail prices by $10 \%$. Operator 2, in face of the imposed wholesale prices, decreases the price of service 1 and service 2 by $30 \%$ and $20 \%$, respectively. A new entrant has to pay the wholesale to the incumbent, but if increase the retail prices their market share will decrease (see model above).

TABLE VII. PURE NE STRATEGIES FOR BOTH REGIONS

\begin{tabular}{|c|c|c|c|c|c|c|}
\hline \multirow{2}{*}{ 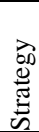 } & \multicolumn{2}{|c|}{$\begin{array}{c}\text { Player } 1 \\
\text { (Incumbent) }\end{array}$} & \multicolumn{2}{|c|}{$\begin{array}{c}\text { Player } 2 \\
\text { (New entrant) }\end{array}$} & \multirow{2}{*}{$\begin{array}{c}\text { NPV } \\
\text { K€ } \\
\text { Player } \\
1 \\
\end{array}$} & \multirow{2}{*}{$\begin{array}{c}\text { NPV } \\
\text { K€ } \\
\text { Player } \\
2\end{array}$} \\
\hline & $\begin{array}{l}\text { Retail } \\
\text { Serv. } 1\end{array}$ & $\begin{array}{c}\text { Retail } \\
\text { Serv. } 2\end{array}$ & $\begin{array}{c}\text { Retail } \\
\text { Serv. } 1\end{array}$ & $\begin{array}{l}\text { Retail } \\
\text { Serv. } 2\end{array}$ & & \\
\hline 1 & $\begin{array}{c}1.1 \\
(22 €)\end{array}$ & $\begin{array}{c}1.1 \\
(55 €)\end{array}$ & $\begin{array}{c}0.7 \\
(14 €)\end{array}$ & $\begin{array}{c}0.8 \\
(40 €)\end{array}$ & 9.565 & 555 \\
\hline 2 & $\begin{array}{c}1.2 \\
(24 €)\end{array}$ & $\begin{array}{c}1.2 \\
(60 €)\end{array}$ & $\begin{array}{c}1.3 \\
(26 €)\end{array}$ & $\begin{array}{c}1.1 \\
(55 €)\end{array}$ & 1.435 & 23.715 \\
\hline 3 & $\begin{array}{c}1.3 \\
(26 €)\end{array}$ & $\begin{array}{c}1 \\
(50 €)\end{array}$ & $\begin{array}{c}1.2 \\
(24 €)\end{array}$ & $\begin{array}{c}0.7 \\
(35 €)\end{array}$ & 5.015 & 3.295 \\
\hline
\end{tabular}

The next figure shows the impact of service 2 variation on NPV of both operators. From the analysis of the next figure we can conclude that the variation of retail prices of service 2 has a greater influence in the NPV than the variation of service 1 price. Service 2 price variation can 
drop the NPV of operator 1 to negative. On the other hand, operator 2 can turn the NPV positive when the tariff of service 2 increases.
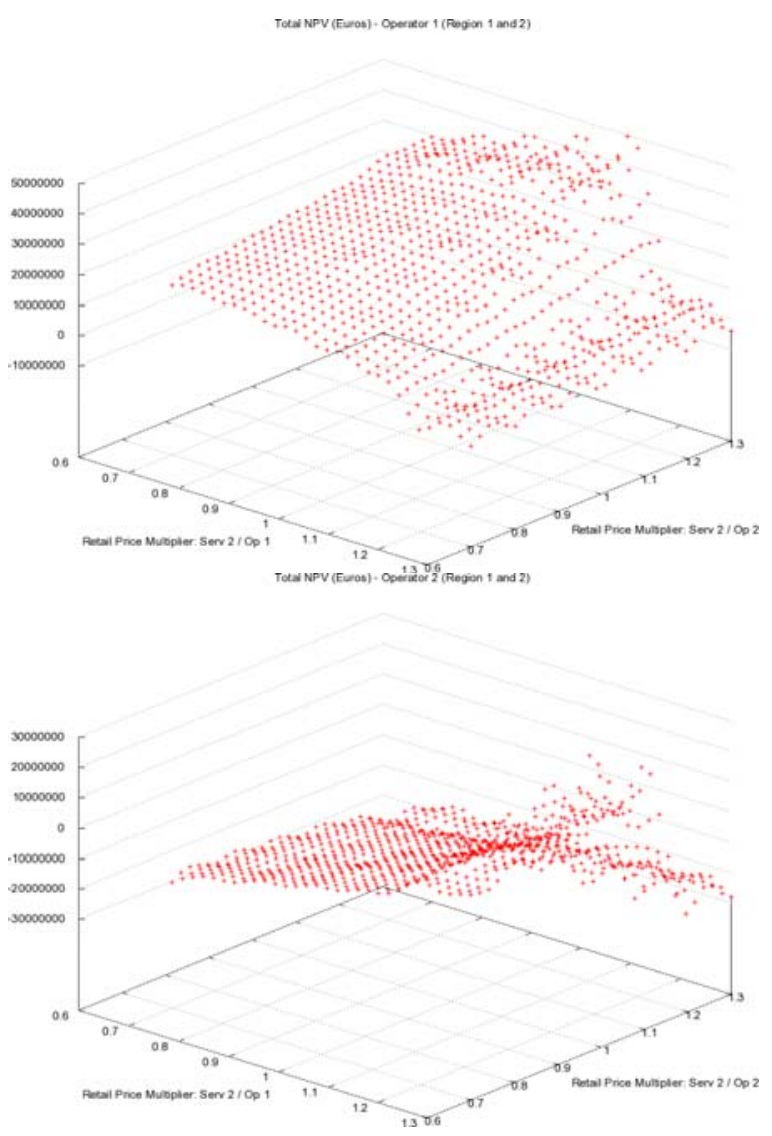

Figure 6. NPV variation: Operator1 and 2/Retail service 2

Game 2: Impact of retail and wholesale prices variation on NPV

In this game we assume that wholesale prices are not pre-imposed and we investigate what is the reaction of operators when they can also choose different wholesale prices in different regions (see next table). In game 2 we assume that has the same variation for both regions. Retail prices vary between $0.8(-20 \%)$ and 1.2 (20\%) (in increments of 0.1 ). For wholesale price we assume a variation between 0.5 and 1.5 (in increments of 0.25 ).

TABLE VIII. RETAIL AND WHOLESALE PRICES VARIATION VALUES FOR GAME 2

\begin{tabular}{|l|c|c|c|c|c|}
\hline Service & \multicolumn{5}{|c|}{ Tariff multiplier factor } \\
\hline Retail price & 0.8 & 0.9 & 1 & 1.1 & 1.2 \\
\hline Wholesale price & 0.5 & 0.75 & 1 & 1.25 & 1.5 \\
\hline
\end{tabular}

In this context, the combination of the three prices and variation multipliers (described in the previous table) leads to 625(5^4) possible strategies for each player (625x625 matrix) in each region (390625 strategies in both regions) - TABLE IX. shows the structure used.

As the matrix is to bigger, for this game we decide to present the NE strategies (players profit is used as payoff) and the graphs that show the impact of variation in the several results (presented in TABLE XII. ).
TABLE IX. STRUCTURE OF COMBINATIONS AND RESULTS FOR GAME 2

\begin{tabular}{|c|c|c|c|c|c|c|c|c|c|c|c|}
\hline \multirow{4}{*}{ 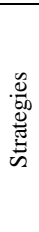 } & \multicolumn{4}{|c|}{ Player 1} & Pl 2 & \multicolumn{6}{|c|}{ Results - NPV } \\
\hline & \multicolumn{2}{|c|}{$\begin{array}{l}\text { Retail } \\
\text { Price }\end{array}$} & \multicolumn{2}{|c|}{$\begin{array}{c}\text { Wholesale } \\
\text { Price }\end{array}$} & $\cdots$ & \multicolumn{2}{|c|}{ Player 1} & \multicolumn{2}{|c|}{ Player 2} & $\begin{array}{l}\text { Tot } \\
\text { P1 }\end{array}$ & $\begin{array}{l}\text { Tot } \\
\text { P2 }\end{array}$ \\
\hline & \multicolumn{2}{|c|}{ R1\& R2 } & R1 & $\mathrm{R} 2$ & $\ldots$ & R1 & R2 & R1 & $\mathrm{R} 2$ & $\begin{array}{c}\mathrm{R} 1 \\
+\end{array}$ & $\begin{array}{c}\text { R1 } \\
+\end{array}$ \\
\hline & S1 & S2 & & & $\cdots$ & & & & & & \\
\hline 1 & 0.8 & 0.8 & 0.8 & 0.8 & $\ldots$ & & & & & & \\
\hline 2 & 0.8 & 0.8 & 0.8 & 0.8 & $\ldots$ & & & & & & \\
\hline $\mathrm{n}$ & $\ldots$ & $\ldots$ & $\ldots$ & $\ldots$ & $\ldots$ & & & & & & \\
\hline
\end{tabular}

The analysis of the results finds five NEs strategies. As player 2 do not operates in the wholesale market of region 1 , the variation of this price is not significant (see next table). We conclude that, in the business case defined, when operators can charge different retail and wholesale prices, they choose to increase wholesale prices. To maximize profits, operators increase wholesale prices and decrease retail prices. However, the increase in wholesale prices precludes entry of new operators into the market.

TABLE $X . \quad$ Pure NE StRategies in Both Regions (GAME 2)

\begin{tabular}{|c|c|c|c|c|c|c|c|c|c|}
\hline \multicolumn{4}{|c|}{$\begin{array}{c}\text { Player } 1 \\
\text { (Incumbent operator) }\end{array}$} & \multicolumn{4}{|c|}{$\begin{array}{c}\text { Player } 2 \\
\text { (New entrant) }\end{array}$} & \multirow{3}{*}{$\begin{array}{c}\text { Profit } \\
\text { (K€) } \\
\text { Player } \\
1\end{array}$} & \multirow{3}{*}{$\begin{array}{c}\text { Profit } \\
\text { (K€) } \\
\text { Player } \\
2\end{array}$} \\
\hline \multicolumn{2}{|c|}{ Retail } & \multicolumn{2}{|c|}{ Wholesale } & \multicolumn{2}{|c|}{ Retail } & \multicolumn{2}{|c|}{ Wholesale } & & \\
\hline S1 & S2 & R1 & R2 & S1 & S2 & R1 & R2 & & \\
\hline 0.8 & 0.8 & 1.25 & 1.25 & 0.8 & 0.8 & $\begin{array}{c}0.50 \\
0.75 \\
1 \\
1.25 \\
1.5\end{array}$ & 1.25 & 22402 & 101 \\
\hline 0.8 & 0.9 & 1.25 & 1 & 0.8 & 0.8 & $\begin{array}{c}0.50 \\
0.75 \\
1 \\
1.25 \\
1.5\end{array}$ & 1.25 & 19543 & 6.198 \\
\hline
\end{tabular}

The main results of this game are summarized in the next figures. In the graphs we can see the impact of retail prices (Figure 7. ) and wholesale prices (Figure 8. ) on players profit. We can verify that both prices can turn profit positive/negative.

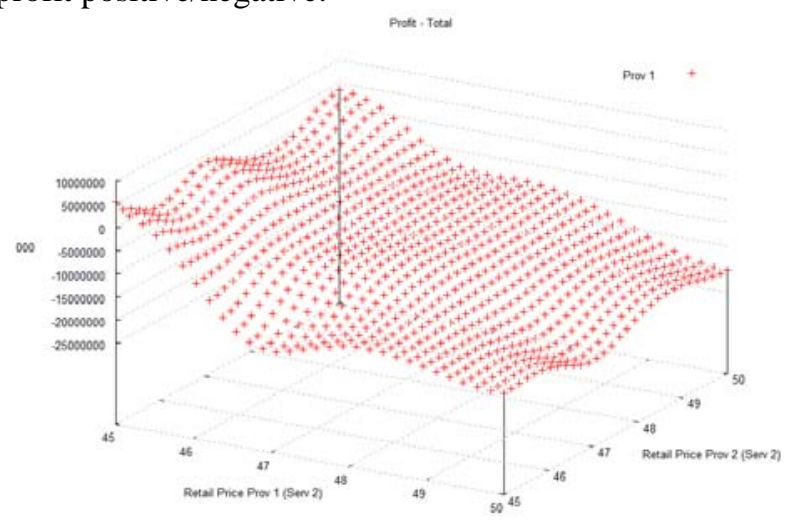

Figure 7. Profit variation: Retail service 2 


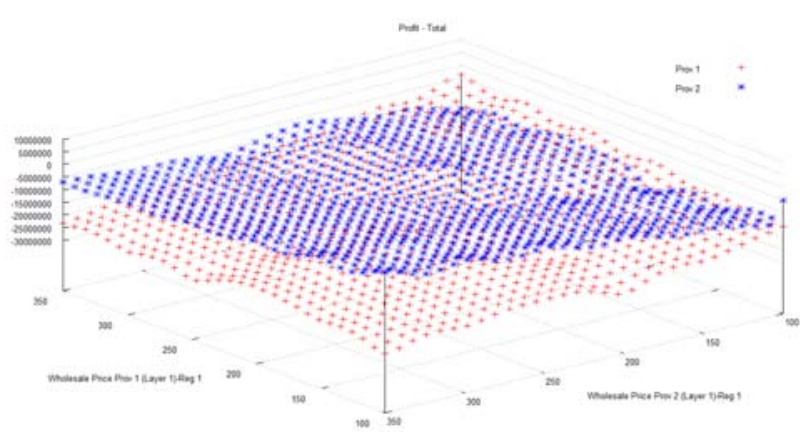

Figure 8. Profit variation: Wholesale service

As expected, consumer surplus decreases with the increase of prices (Figure 9. ). As also predictable and modeled above the impact of retail prices variation has higher influence in the market share of competitors (see Figure 10. ).

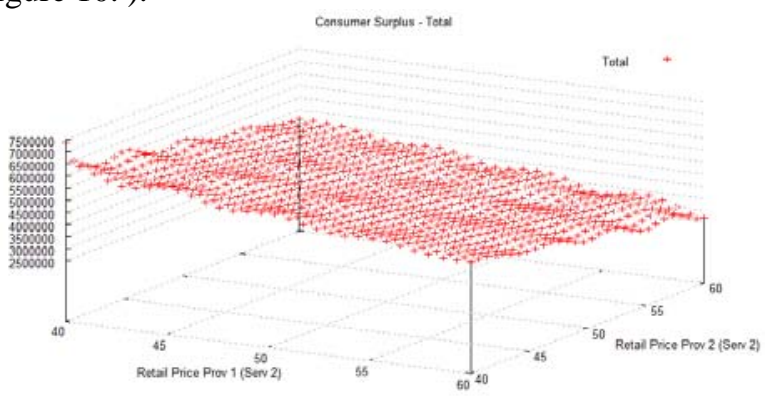

Figure 9. Consumer Surplus variation

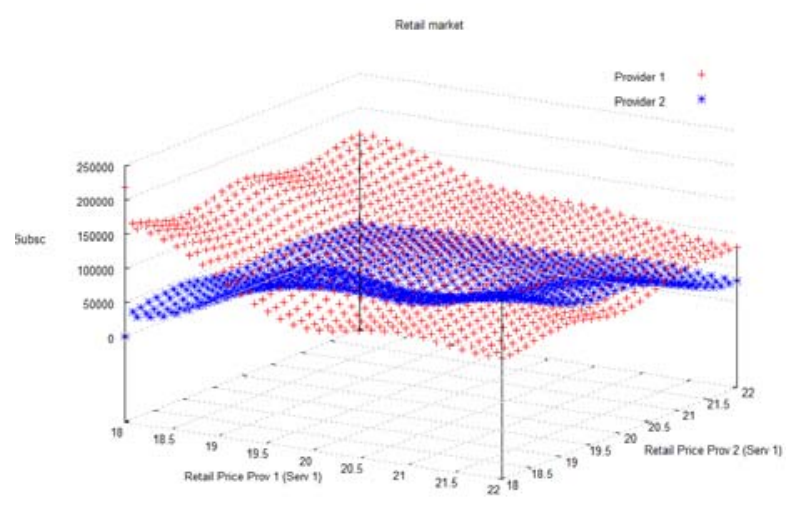

Figure 10. Retail market variation

The comparison of the two games above shows that when the regulator defines wholesale prices, operators increase retail prices to maximize profit. However, when wholesale prices are not regulated, operators maximize profit by decreasing retail prices and increasing wholesale prices. However, without regulation, the higher wholesale prices will limit the entrance of new competitors.

\section{CONCLUSIONS}

The European Commission argues that infrastructurebased competition is the best and fastest way for broadband development. The arguments are that infrastructure-based competition provides efficiency incentives to operators, reduces prices, increase penetration, stimulates innovation, and so on. On the other hand, service-based competition implies that the new entrants (alternative operators) are dependent on the incumbent. However, because of the high costs of deploying infrastructures (especially trenching and ducting), service competition has been used as a substitute or complement to infrastructure competition. In regions with lower numbers of existing access infrastructures, new entrants are obligated to build their own infrastructure. In this way, infrastructure sharing can stimulate the construction of new access infrastructures that can be leased to other operators.

The results of this investigation show that the sharing of passive infrastructures (e.g., ducts, trenching, base station sites, antenna masts, etc.) is a viable strategy, particularly in the context of new building (in scenarios with developed access infrastructure). When an operator deploys an access network, the access to existing civil engineering significantly reduces the investment. There are strong arguments to be made for allowing infrastructure sharing.

In this context, regulators must guarantee new entrant operators access to civil engineering; this will stimulate investment in new networks. The reduction of the barriers to new infrastructure investment by opening passive existing infrastructure would be key in the future. This study has shown that in rural areas, characterized by a small number of developed access infrastructure, the access to civil engineering does not make the scenario economically viable for the operator.

\section{REFERENCES}

1. S.L. Kota, "Satellite Multimedia Networks and Technical Challenges," Microwave Review, 2006.

2. O.C. Ibe, Fixed Broadband Wireless Access Networks and Services, John Wiley \& Sons, Inc., 2002.

3. J.P. Pereira and P. Ferreira, "Access networks for mobility A techno-economic model for broadband access technologies," Proc. Testbeds and Research Infrastructures for the Development of Networks \& Communities and Workshops, 2009. TridentCom 2009. 5th International Conference on, 2009, pp. 1-7.

4. J.S. Marcus, et al., Next Generation Networks (NGNs), European Parliament, 2009.

5. F. Kirsch and C.V. Hirschhausen, "Regulation of Next Generation Networks: Structural Separation, Access Regulation, or no Regulation at all?,” Proc. First International Conference on Infrastructure Systems and Services: Building Networks for a Brighter Future (INFRA), 2008, pp. 1-8.

6. J.P. Pereira, "Telecommunication Policies for Broadband Access Networks," Proc. The 37th Research Conference on Communication, Information and Internet Policy, 2009, pp. 1-13.

7. Analysys-Mason, Telecoms infrastructure access - sample survey of duct access, Ofcom, 2009.

8. J.P. Pereira and P. Ferreira, "Next Generation Access Networks (NGANs) and the geographical segmentation of markets," Proc. The Tenth International Conference on Networks (ICN 2011), 2011, pp. 6.

9. C. Jaag and M. Lutzenberger, "Approaches to FTTHRegulation: An International Comparison,” Proc. Second Annual Conference on Competition and Regulation in Network Industries, 2009, pp. 23. 
10. J. Rendón, et al., "A business case for the deployment of a 4G wireless heterogeneous network in Spain,” Proc. 18th European Regional International Telecommunications Society, 2007.

11. T. Monath, et al., "Economics of Fixed Broadband Access Network Strategies,” IEEE Communications Magazine, vol. 163, no. 8, 2003, pp. 132-139.

12. F. Loizillon, et al., Final results on seamless mobile IP service provision economics, IST- Information Society Technologies, 2002.

13. T. Monath, "Techno-economic results for fixed access network evolution scenarios," Book Techno-economic results for fixed access network evolution scenarios, Series Techno-economic results for fixed access network evolution scenarios, ed., Editor ed.^eds., 2005, pp. 28.

14. Analysys-Mason, The costs of deploying fibre-based nextgeneration broadband infrastructure, Analysys-Mason, Broadband Stakeholder Group, 2008.
15. CSMG, Economics of Shared Infrastructure Access, 2010.

16. K. Stordahl, "Broadband demand and the role of new technologies," Proc. Telecommunications Network Strategy and Planning Symposium, 2008. Networks 2008. The 13th International, 2008, pp. 1-23.

17. K. Stordahl, Market development up to 2015, MARCH Multilink architecture for multiplay services, 2010.

18. K. Stordahl, et al., "Risk methodology for evaluating broadband access network architectures," Telektronikk, vol. 2, no. 3, 1999, pp. 273-285.

19. V. Riihimäki, "Managing Uncertainties in Broadband Investments- Case Studies of Real Options for Rural Area Access Networks," Department of Communications and Networking, Aalto University, Aalto, FI, 2010.

20. European-Union, Europe's Digital Competitiveness Report 2010, European Union, 2010.

TABLE XI. GAME 1 RESULTS - SUMMARY

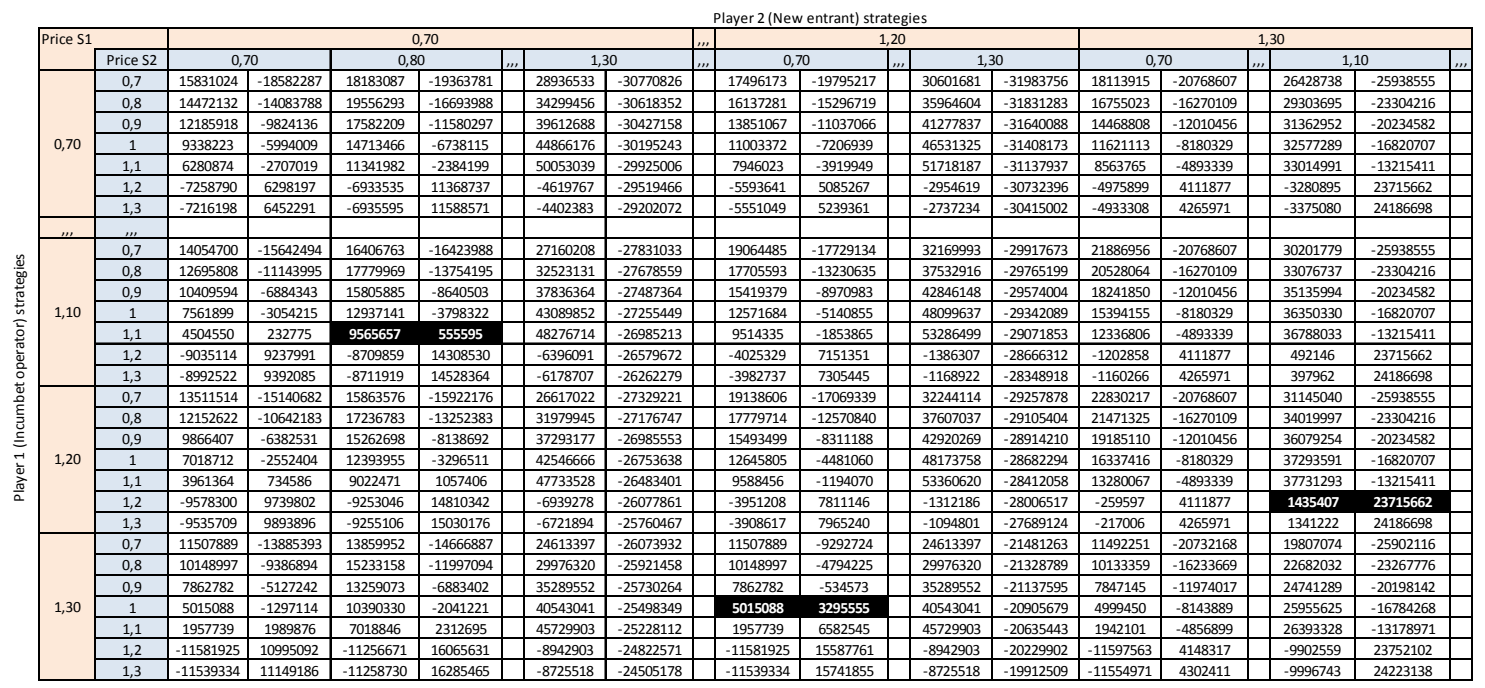

TABLE XII. GAME 2 RESULTS - SUMMARY

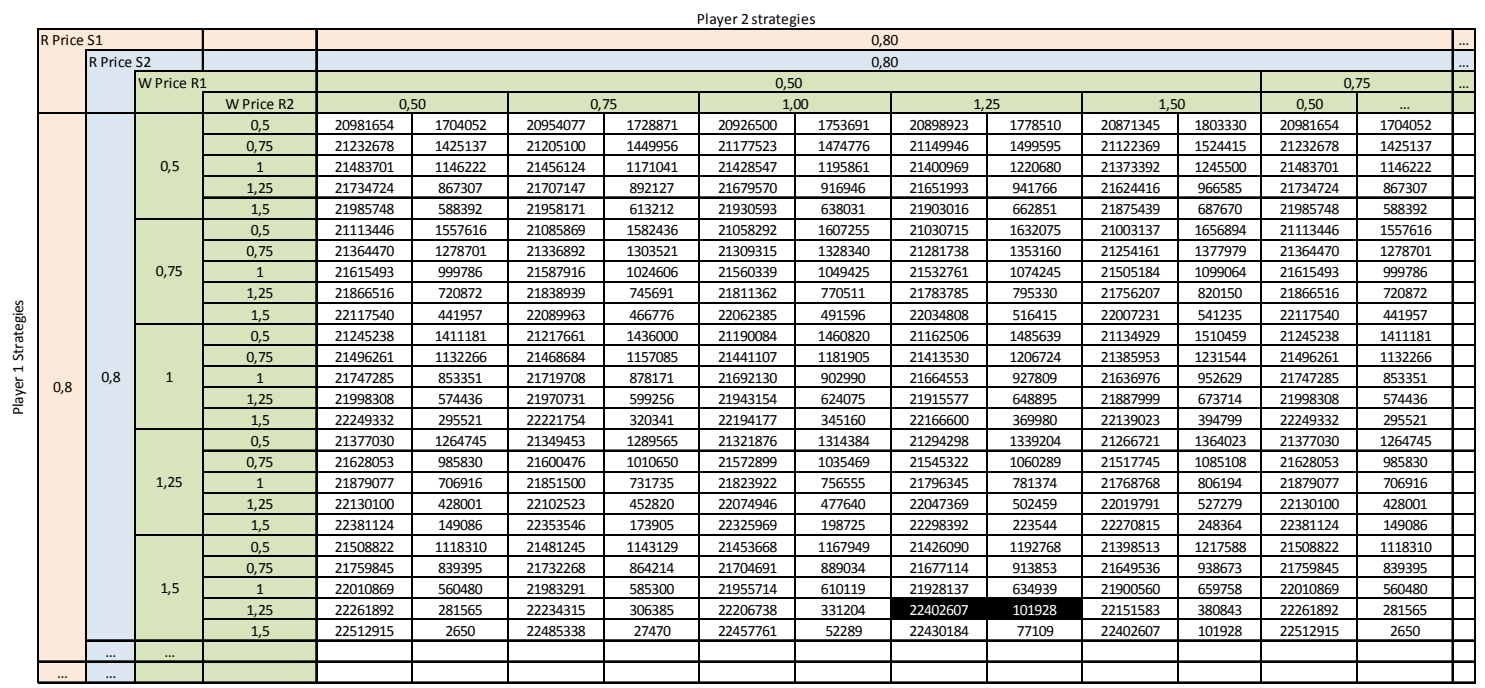

